\title{
Suburbanisation versus recentralisation. Changes in the effect of international migration inflows on the largest Spanish metropolitan areas (2000-2010)
}

\author{
JORDI BAYONA-I-CARRASCO ${ }^{1}$ \\ FERNANDO GIL-ALONSO ${ }^{1}$ \\ ISABEL PUJADAS-I-RÚBIES ${ }^{1}$
}

\begin{abstract}
Résumé
Cet article analyse comment l'évolution de l'immigration internationale a influé sur les changements et la composition démographique des grandes aires urbaines en Espagne, en se concentrant sur l'impact des étrangers sur les dynamiques des zones périurbaines et des centres urbains. Depuis 2000, l'Espagne est le pays européen qui a accueilli le plus d'étrangers. La part des résidents étrangers a cru de seulement $2,3 \%$ en 2000 à $12,2 \%$ en 2010 . De plus, les étrangers ne sont pas répartis uniformément dans le pays, et se sont concentrés dans certaines provinces offrant des emplois dans le tourisme, les services ou l'agriculture intensive, ainsi que dans les grandes zones urbaines. L'article porte sur ce dernier phénomène en analysant les quinze plus grandes métropoles espagnoles ayant plus d'un demi-million d'habitants. Selon les données de 2010, les proportions d'étrangers vivant dans ces villes diffèrent grandement variant de $17,5 \%$ et $17,4 \%$ à Madrid et Barcelone, jusqu'à $5,3 \%$ et $1,7 \%$ à Séville et Cadix. Après deux décennies de stagnation ou de baisse, ces proportions ont nettement augmenté durant la décennie 2000, essentiellement en raison de l'immigration étrangère. Durant le même temps, la périurbanisation, à laquelle les étrangers ont aussi participé, s'est également intensifiée. Cet article examine aussi l'impact de la crise économique qui a débuté en 2008 sur les métropoles espagnoles.
\end{abstract}

1. Human Geography Department, Universitat de Barcelona, Spain. 


\section{Mots-clés}

Croissance urbaine, population étrangère, péri-urbanisation, aires métropolitaines, Espagne.

\section{Summary}

This paper analyses how international immigration developments have influenced the population change and composition in Spain's largest urban areas, focusing on the impact of foreigners on suburbanisation and re-centralisation dynamics. Since 2000 , Spain has been the European country with the largest international migration inflows. As a result, the share of foreign residents has increased from a mere $2.3 \%$ in 2000 to $12.2 \%$ in 2010 . Moreover, they have unevenly settled throughout the country, concentrating in specific provinces specialised in tourism, services or intensive agriculture jobs, as well as in large urban areas. The paper concentrates on this latter aspect, analysing Spain's fifteen largest metropolitan areas, with more than half a million inhabitants. In 2010, percentages of foreigners living in these core cities range from $17.5 \%$ and $17.4 \%$ in Barcelona and Madrid to $5.3 \%$ or $1.7 \%$ in Seville and Cadiz. After two decades of stagnation or even decrease, central city figures clearly regained strength, due to foreign immigration, during this 2000-2010 period. At the same time, suburbanisation - to which foreigners also contributed has also intensified. The paper provides an overview of recent population changes in Spanish metropolitan areas, evaluates the effect of the massive arrival of foreign immigrants on Spain's urban development - analysing cores and peripheries separately; and assesses the impact of the economic crisis which started in 2008, on these trends.

\section{Keywords}

Urban growth, foreign population, suburbanisation, metropolitan areas, Spain.

\section{Introduction ${ }^{2}$}

Due to an intense and unexpected foreign immigration rise, Spain's population has abruptly increased. In a decade, the country's population leaped from 40 million - considered in some early 1990s population

2. This paper is a result of three $\mathrm{R}+\mathrm{D}$ projects: «The new Spanish cities. The territorial impact of recent population dynamics in Spain's largest urban areas» (CS02011-24680), directed by Dr. Isabel Pujadas; «Residential strategies and urban models at the RMB» (CSO2010-22117-C02-02), directed by Dr. Cristina López; and «Spain's demographic dynamics through the 20th Century Censuses» (CSO2008-06217), directed by Dr. Fernando Gil. These research projects are financed by the Spanish Ministry of Science and Innovation through the 2008-2011 $R+D+$ I National Plan. Authors are members of the Population, Territory and Citizenship Research Group, directed by Dr. Isabel Pujadas (2009SGR01086). 
projections (Instituto de Demografía, 1994) as Spain's ceiling - to 47 million inhabitants. This is the highest absolute and relative growth in one decade since 1900 . Foreigners played a key role in the process, as they were responsible for at least three quarters of the growth. Leaving naturalizations and children from mixed marriages aside, foreign immigration numbers multiplied by six, increasing from 923'879 in 2000 to $5^{\prime} 747^{\prime} 734$ ten years later, therefore augmenting from $2.3 \%$ to $12.2 \%$ of the population. However, due to the uneven spatial distribution of foreigners, certain areas have been more affected than others. While many cities have been considered by foreign immigrants as attraction points, others have hardly been impacted. As a consequence, in 2010 the percentage of foreigners ranges from $17.5 \%$ in the cities of Barcelona and Madrid to $5.3 \%$ in Seville and $1.7 \%$ in Cadiz.

In the mid-1990s, population stagnation (or even decrease in major cities), suburbanisation and metropolitan expansion dominated Spanish urban systems. Then, these trends were abruptly interrupted by a surge of foreign migrants, which initiated a completely new urban demographic growth cycle (Pujadas et al., 2012). Core-city decline stopped and some even gained residents once again, as foreigners compensated for native population loss. Meanwhile suburban flows - mainly of Spanish people, and increasingly of foreign immigrants - continued to grow. This demographic and geographic expansive cycle ends in 2008, when the global economic crisis strikes Spain and foreigner inflows start to decrease.

This latter period has already lasted for several years, and therefore some conclusions can be drawn, both from changes brought by high immigration years and from the effects of the economic crisis. Subsequently, we aim to: 1) provide an overview of recent population changes in Spanish metropolitan areas; 2) evaluate the effect that large arrivals of foreign immigrants have had on Spain's urban development - analysing cores and peripheries separately; and finally 3) assess the impact of the current economic crisis on these trends.

\section{Literature review}

Just before the global economic crisis started in 2008, Spanish cities were going through a third stage of urban development. A first concentration period (1959-1975), characterised by rural exodus and urbanisation, was followed by a dispersion stage, the so-called suburbanisation 
period (1975-1996), in which the main cities lost population while their peripheries grew strongly (Nel-lo, 2007). After a short transition, at the turn of the century, Spanish cities entered a third phase, which for this paper's purposes we consider as lasting from 2000 to 2007. This stage is characterised by intense suburbanisation combined with renewed urban core growth. From 2001 onwards, Kabisch and Haase (2011) also observe a similar process in other southern European cities. However, the Spanish case would have been somewhat different as it did not follow the usual recentralisation model, in which natives return to the urban centre (Cheshire, 1995; Champion, 2001a). Those moving into metropolitan cores are no longer Spanish people. The latter continue in fact to leave most core cities, although López-Gay (2011) believes that this trend is slowing down and that, in the near future, it will cease. Those moving into metropolitan cores are instead foreign immigrants (Bayona, Gil-Alonso, 2008 for Barcelona; or Pozo, García, 2011, for Madrid) who arrived during Spain's two decade long immigration boom, which actually intensified in the early 21 st century.

This third phase ends when the economic crisis erupts, particularly hitting the real estate market from 2008 onwards. Consequently, a fourth phase is initiated. As it is a very recent process at the time of writing (2014), a theoretical framework which takes into account the impact of recession on urban development is not yet available. Instead, we have applied the classical cyclical urbanisation model built by Van den Berg et al. (1982). This four-stage urban development model has been employed by several authors (Cheshire, 1995; Turok, Mikhnenko, 2007; Kabisch, Haase, 2011) to compare European urban trends, and explain past and present population changes in core and fringe. It is a functional model which describes urban growth and decline through four sequential stages: urbanisation, suburbanisation, de-urbanisation and reurbanisation ${ }^{3}$. Each of them would in turn be sub-divided into two periods of relative or absolute core population increase (centralisation) or decrease (decentralisation).

3. In a first stage, that of urbanisation, the core city gains more population than the surrounding area, while the opposite occurs in the following phase, suburbanisation. Even though during suburbanisation urban areas, as a whole, continue to grow, in the following phase, desurbanisation, this is no longer so. Both core city and fringe areas lose population, resulting in decadent urban areas (Medhurst, Lewis, 1969; Andersen, 2003; Oswalt, 2003; Hall, 2006; Ebers, 2007). Finally, in the fourth and final stage, reurbanisation, the core city's population progressively recovers and fringe areas later reduce their decline. 
This model has, however, received several criticisms. For instance, a recent contribution made by Kabisch and Haase (2011) confronted the theoretical model to European evidence from the last two decades, concluding that «no consecutive order of the stages of urban development was identified. Rather, we would support the idea that the regular onward cycle of the stages of urban development (van den Berg et al., 1982) was proven to have been reversed, due to the trends of reinforcing suburbanisation and developing reurbanisation after 2001» (Kabisch, Haase, 2011, p. 246). Therefore, several stages coexisted during this last decade, while significant differences between European regions emerged. Whereas de-urbanisation dominated Eastern European agglomerations, suburbanisation prevailed in the other three European regions - Northern, Western and Southern Europe. Moreover, reurbanisation trends were additionally increasingly observed, even though the Van den Berg et al. (1982) model considered this fourth stage as purely hypothetical and unlikely.

Indeed, population data collected in the 1990s and early 21st century confirms that some core cities are once again gaining population. Thus, reurbanisation - together with continuous suburbanisation - would in fact be taking place (Lever, 1993; Cheshire, 1995; Ogden, Hall, 2000; Haase et al., 2005). This urban population recovery phase is seemingly being caused by two parallel flows. The first one is made of autochthonous people, particularly youngsters, who are seeking better educational and work opportunities, or who are attracted by core cities due to their positional advantages and way of life (Champion, 2001b; Buzar et al., 2005). As Van de Kaa (1987) and Lesthaeghe (1995) claim, such movements would also be related to household structure and lifestyle changes of the Second Demographic Transition. The second flow consists of foreign immigrants who are mainly moving into core cities for labour reasons. This trend would be particularly relevant in Spain and other South European countries due to their highly segregated labour markets (Domingo, Gil-Alonso, 2007), which offer international immigrants numerous low-paid jobs and favour their settlement in the core cities.

These criticisms have led us to redefine the Van den Berg et al. (1982) model so that the four-stages of urban development can fit recent changes in Spain better. The first urbanisation stage would have been followed by the suburbanisation one, then by a third phase combining reurbanisation and suburbanisation (2000-2007) and, finally, by a fourth stage - the present one (2008-2010) - whose characteristics we are still trying to understand. This reformulated theoretical framework 
is used to analyse urban change in the largest Spanish urban areas and to compare the current period of recession with the previous economic expansion period. Foreign and local populations will be examined separately so that we are able to assess the impact of foreign immigration on each period.

\section{Data sources and Urban Areas definition}

Two statistical data sources, collected and published by the Spanish National Statistical Institute (INE), have been used: the Padrón continuo or the local continuous register - referenced to the 1st of January of each year - collecting data on the stock of Spanish and foreign nationality population; and the Movimiento Natural de la Población (MNP) or the natural population movement statistics, gathering births and deaths. The Padrón continuo results from coordinating and crosschecking municipal administrative registers called padrones municipales. It is updated each year the $1^{\text {st }}$ of January, giving, since 1998, the official population figure for each Spanish municipality and for the country as a whole. It crosses the population's age and sex by their place of residence and nationality. According to Spanish law on municipalities (Ley de Bases de Régimen Local), everyone residing in the country - irrespective of their legal situation - has the right and obligation to be registered in their local padrón. Foreigners, including recent and irregular immigrants, usually do it as this gives them access to free public health and education. Therefore, its figures are considered to be a relatively good estimate of the actual number of foreigners living in Spain. On their side, the INE produces the Movimiento Natural de la Población using the birth, marriage and death bulletins it receives from the local Registros Civiles (Civil Registers). Overall birth and death figures are used in this study to obtain urban area migratory growth figures by subtracting natural growth (births minus deaths) from total population growth between two successive years (obtained from Padrón data). Stock and flow data have been disaggregated by nationality (foreign or Spanish). Core-city (the municipality/municipalities leading and giving the name to each area) and periphery (the rest of municipalities) have been distinguished for each urban area.

The difficulty to obtain harmonized data, due to the absence of homogeneous official definitions of Spanish metropolitan areas, has led several authors such as Nel-lo (2004), Serrano (2007), or Feria (2011) to propose different numbers of metropolis, using different delimitations. $\mathrm{Ne}$ - 
vertheless, none of them have been officially adopted. Therefore, for this article, we have decided to use the limits suggested by the Atlas de las Áreas urbanas de España ${ }^{4}$ (Ministerio de la Vivienda, 2006) and to define «large urban areas» as those which have over 500'000 inhabitants. Fifteen metropolitan areas fulfilled the requirements. Even though the Atlas uses administrative limits which don't always reflect population dynamics, employing its criteria allows comparability with other studies using the same administrative definitions.

Eleven out of the fifteen urban areas correspond to the classical definition of a metropolitan area - a core city giving it its name and a metropolitan periphery. However, the other four are formed by a couple of centres. This is the case of Alicante-Elche, Vigo-Pontevedra, the central Asturias urban area, which has the cities of Oviedo and Gijón as its metropolitan centres, and finally of Bahía de Cadiz, which has two cores, Cadiz and Jerez de la Frontera. The number of municipalities within these metropolitan areas ranges from four (Las Palmas de Gran Canaria) to 164 (Barcelona) or 178 (Madrid). In total, 564 municipalities, representing $7 \%$ of the 8'114 in the country have been analysed. They total more than 21 million inhabitants, i.e. $46.6 \%$ of the Spanish population.

\section{The context: Foreign immigration in Spain}

Since the mid 1990's, and particularly from the early 21st century, Spain has undergone a foreign immigration boom (Domingo, Recaño, 2010), becoming during several years the European country with the largest immigration flows. Immigration peaked in 2007 , registering $920^{\prime} 000$ foreign immigrant entries. In 2008 , this trend was abruptly interrupted by the economic crisis. In 2010, foreigner figures stabilised at around 5.7 million, i.e. $12.2 \%$ of the population. However, a decade before they were less than one million and did not represent more than $2.3 \%$ of the population (Figure 1).

\footnotetext{
4. The only exception to this criterion has been the case of the Madrid metropolitan area. Instead of using its Atlas de las Áreas urbanas de España definition and limits, which are very restrictive, we have defined it as the whole Autonomous Community (administrative region). Actually, the real metropolitan area of Madrid has expanded beyond this administrative border and suburbanisation has reached the neighbouring Castilla-La Mancha region.
} 
FIGURE 1 Foreign population growth, 1998-2011

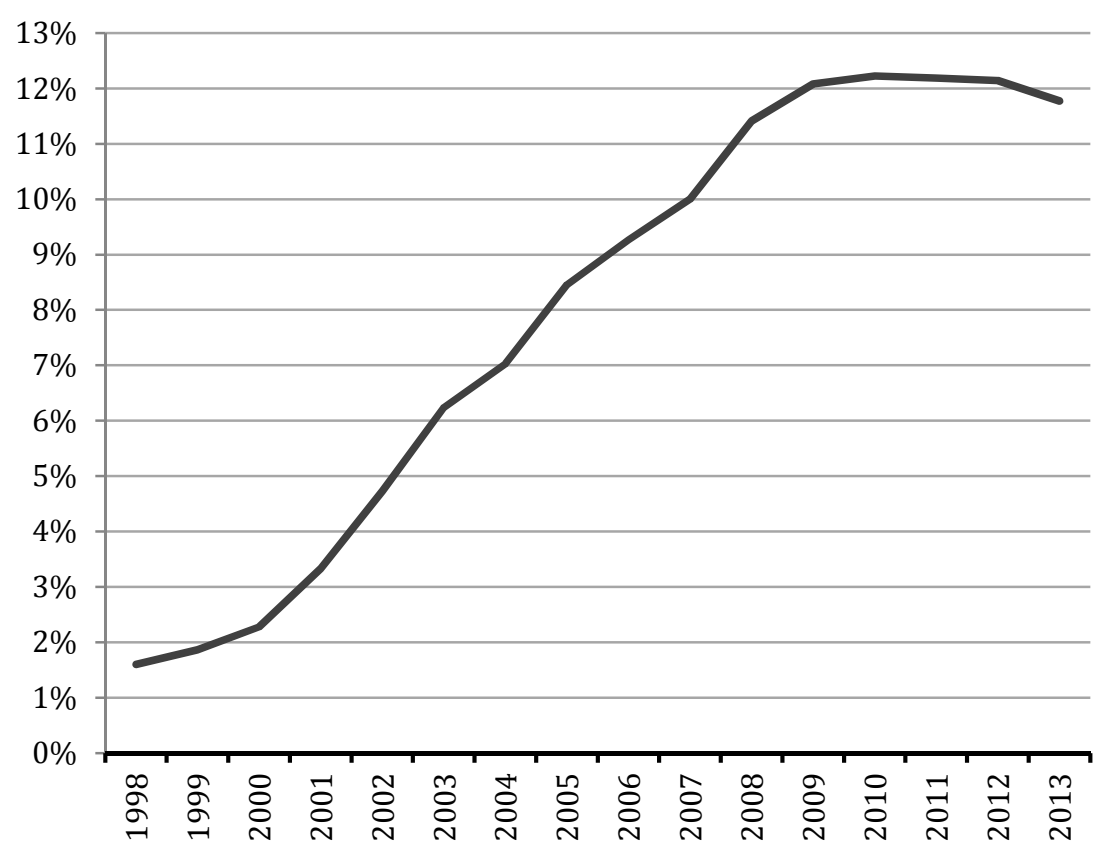

Source: INE, Padrón continuo (http://www.ine.es/inebmenu/mnu_padron.htm).

These migration trends imply that Spain has rapidly changed from a traditionally emigration country ${ }^{5}$ to an immigration one. The first foreign flows started to arrive in the late 1970s. They consisted of a few Moroccans - who had increasing difficulties to enter other European countries - and Latin-Americans from very specific countries who had frequently emigrated for political reasons. From the 1990s onwards, both started to grow. The Latin-American flow consisted at first mainly of Peruvians. From 2000, it was made up of Ecuadorians and finally, various countries of Latin-America. Around 2005, Central and Eastern European flows also started to grow. In fact, Romanians form since 2008 the largest single foreign nationality in Spain. Asian migrants (particularly from China and Pakistan) should also be mentioned. Finally, significant numbers of former EU-15 citizens, who in some coastal regions are mainly retired people, should also be taken into account. Thus, foreign population in Spain is extremely heterogeneous. However, specific national origin and sex or age groups do tend to live in certain municipali-

5. According to the Padrón de Españoles Residentes en el Exterior, in 2011 there were still 1.7 million Spaniards living outside Spain, $23.8 \%$ of which aged 65 or over. 
ties depending on their size and the main activity they develop (Figure 2). For example, while Asians are practically absent from municipalities under 1'000 inhabitants, they tend to live in large cities, where they represent $12.4 \%$ of migrants in 2010 . In fact, one in three Asians resides in Madrid or Barcelona. Latin-Americans mainly work in the tertiary economic sector and their numbers also increase with the size of the city (Vono, 2010; Gil-Alonso, Domingo, 2008). Africans avoid large cities and only represent $7.4 \%$ of the foreigners living in Madrid or Barcelona. Finally, Europeans are over-represented in small municipalities. While EU citizens have mainly moved to suburban or tourist municipalities ${ }^{6}$, Romanians, Bulgarians and East Europeans tend to live in rural areas where they usually work in agriculture, agro-industry or construction.

FIGURE 2 Foreign population distribution by municipality size and origin, Spain 2010

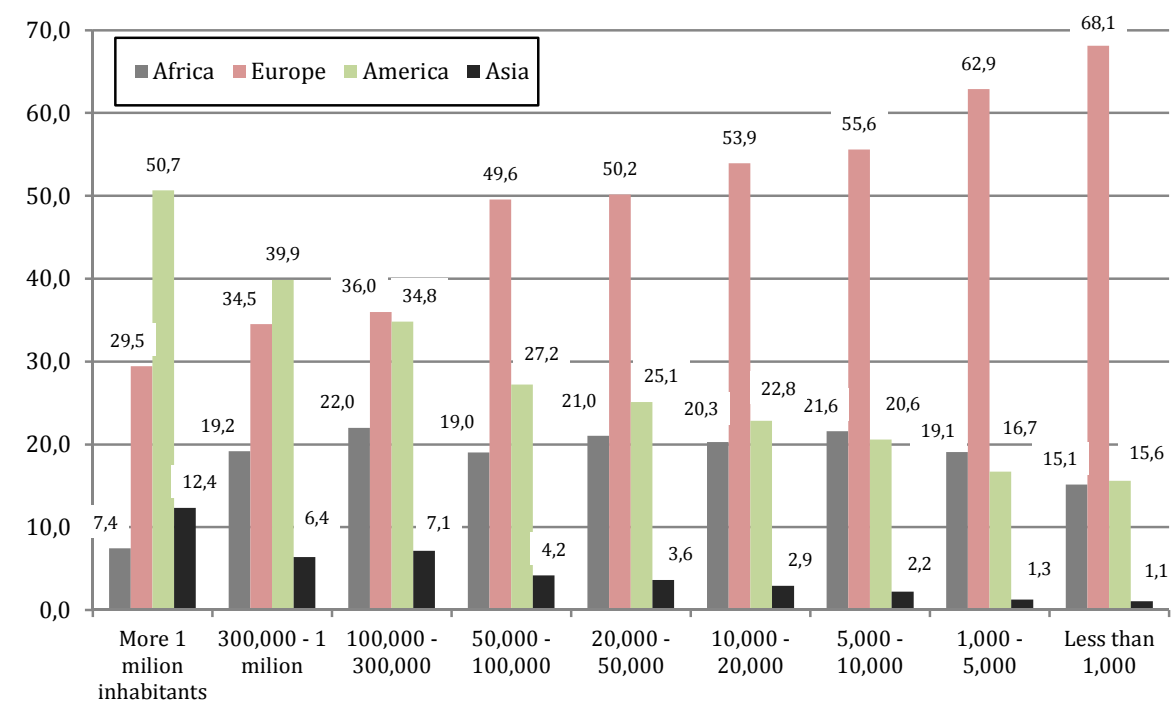

Source: INE, Padrón continuo (http://www.ine.es/inebmenu/mnu_padron.htm).

While only $828(10.4 \%)$ out of the 8'114 Spanish municipalities have no foreigners at all, immigrants particularly concentrate in tourist seacoast localities near intensive agriculture sites, and in large urban areas. Half of the foreigners living in Spain reside in one of the fifteen metropolis

6. Mediterranean coastal tourist municipalities are the places with the highest foreigner shares. In 31 of them, they (mainly, British and German people) represent more than half of the population. 
analysed in this article. However, they are not homogenously distributed among them. While some cities like Barcelona and Madrid have a high percentage of foreigners - around $17.5 \%$ in both of them, and above $20 \%$ in some municipalities therein (Bayona, 2007) -, other cities like Seville or Cadiz have much lower figures (5.3\% and $1.7 \%$ respectively).

\section{Urban population growth, 2000-2010}

In the first decade of the 21st century, Spain's population increased from 40.5 to 47 million. As a result, the population in main metropolitan areas also increased. The 18'707'065 residents living in the 564 municipalities studied in the year 2000 turned 21'908'157 ten years later (Table 1). These three more million inhabitants account for more than half of Spain's demographic increase. Their annual cumulative growth rate ${ }^{7}$ was $1.59 \%$ (1.43\% for the rest of Spain). However, not all metropolitan areas experienced the same trend. Growth was particularly high in Madrid $(2.19 \%)$ and in the Mediterranean coastal urban areas such as Murcia (2.42\%), Palma de Mallorca (2.39\%), Malaga (2.28\%), or Alicante $(2.19 \%)$. As table 1 shows, these are precisely the urban areas which have the highest foreign population shares.

The less dynamic metropolitan areas have, on the contrary, received few immigrants. These areas (Bilbao, Asturias, Vigo-Pontevedra, Las Palmas de Gran Canaria and Bahía de Cadiz) also have the lowest percentages of foreigners (Table 1). Granada is the only exception: despite a relatively low percentage of foreigners, well under the Spanish mean, its population has grown more than Spain as a whole due to relatively high natural growth. On the contrary, the population of Barcelona, Zaragoza and Valencia has grown a little less than the Spanish mean, even though they all have relatively high foreign population percentages. Therefore, we can draw two conclusions. On the one hand, we can claim that, except in certain specific cases, there is a positive relationship between immigration and population growth in the largest urban areas. On the otherhand, we should also underline that not all urban areas have received the same volume of immigrants. In 2010, seven of the areas analysed

7. Cumulative annual growth rate or $\mathrm{r}(\%)$ formula for a given period is $r=\left(\sqrt[t]{P_{t} / P_{0}}-1\right) \times 100$, where $t$ is the time span (in years), $P_{t}$ is the population at the end of the period and $\mathrm{P}_{0}$ the period's initial population. 
had substantially less foreigners than the Spanish mean, the Bahía de Cadiz municipalities being those with the smallest share, i. e. $2.7 \%$ of foreign population. At the other end, the Palma de Mallorca urban area reaches $21 \%$.

TABLE 12000,2008 and 2010 population, share of foreigners and mean annual growth rates in the main Spanish metropolitan areas

\begin{tabular}{|c|c|c|c|c|c|c|c|}
\hline & 2000 & $\begin{array}{l}\% \text { for- } \\
\text { eigners }\end{array}$ & 2008 & $\begin{array}{l}\% \text { for- } \\
\text { eigners }\end{array}$ & 2010 & $\begin{array}{l}\% \text { for- } \\
\text { eigners }\end{array}$ & $\begin{array}{c}r(\%) \\
2000-10\end{array}$ \\
\hline Alicante-Elche (6) & $561^{\prime} 070$ & 4.6 & $685^{\prime} 754$ & 15.9 & $697^{\prime} 039$ & 16.4 & 2.19 \\
\hline Bahía de Cadíz (6) & $582^{\prime} 434$ & 0.6 & $630^{\prime} 826$ & 2.4 & $639^{\prime} 172$ & 2.7 & 0.93 \\
\hline Barcelona (164) & $4^{\prime} 328^{\prime} 447$ & 2.6 & $4^{\prime} 928^{\prime} 852$ & 14.0 & $5^{\prime} 012^{\prime} 961$ & 14.9 & 1.48 \\
\hline Bilbao (35) & $906^{\prime} 222$ & 0.8 & 906 '399 & 5.1 & $910^{\prime} 085$ & 5.9 & 0.04 \\
\hline $\begin{array}{l}\text { Central de Asturias } \\
\text { (18) }\end{array}$ & $806^{\prime} 028$ & 0.8 & $828^{\prime} 288$ & 4.1 & $836^{\prime} 141$ & 7.3 & 0.37 \\
\hline Granada (30) & $432^{\prime} 062$ & 1.0 & $494^{\prime} 799$ & 5.3 & $511^{\prime} 815$ & 5.5 & 1.71 \\
\hline Madrid (178) & $5^{\prime} 198^{\prime} 622$ & 3.2 & $6^{\prime} 271^{\prime} 638$ & 16.0 & $6^{\prime} 458^{\prime} 684$ & 16.7 & 2.19 \\
\hline Málaga (8) & $752^{\prime} 502$ & 5.4 & $915^{\prime} 715$ & 14.7 & $942 \prime 919$ & 15.7 & 2.28 \\
\hline Murcia (10) & $504^{\prime} 534$ & 1.3 & $623^{\prime} 219$ & 13.4 & $641^{\prime} 043$ & 14.0 & 2,42 \\
\hline Palma de Mallorca (8) & $430^{\prime} 697$ & 5.2 & $532 \prime 659$ & 19.9 & $545^{\prime} 550$ & 21.0 & 2.39 \\
\hline $\begin{array}{l}\text { Palmas Gran Canaria, } \\
\text { L. (4) }\end{array}$ & $496^{\prime} 754$ & 2.5 & $534^{\prime} 908$ & 6.4 & $540 \prime 088$ & 6.6 & 0.84 \\
\hline Sevilla (24) & $1^{\prime} 162^{\prime} 712$ & 0.7 & $1^{\prime} 258^{\prime} 287$ & 3.7 & $1^{\prime} 286^{\prime} 677$ & 4.5 & 1.02 \\
\hline Valencia (45) & $1^{\prime} 353^{\prime} 279$ & 1.3 & $1^{\prime} 535^{\prime} 028$ & 11.5 & $1^{\prime} 557^{\prime} 907$ & 12.2 & 1.42 \\
\hline Vigo-Pontevedra (14) & $549^{\prime} 776$ & 1.1 & $580^{\prime} 103$ & 4.3 & $586^{\prime} 505$ & 4.6 & 0.65 \\
\hline Zaragoza (14) & $641^{\prime} 926$ & 1.1 & $726^{\prime} 332$ & 11.8 & $741^{\prime} 571$ & 12.8 & 1.45 \\
\hline $\begin{array}{l}\text { Main metropolitan } \\
\text { areas }\end{array}$ & $18^{\prime} 707^{\prime} 065$ & 2.4 & $21^{\prime} 452^{\prime} 807$ & 12.2 & $21^{\prime} 908^{\prime} 157$ & 13.0 & 1.59 \\
\hline Spain & $40^{\prime} 499^{\prime} 791$ & 2.3 & $46^{\prime} 157^{\prime} 822$ & 11.4 & $47^{\prime} 021^{\prime} 031$ & 12.2 & 1.50 \\
\hline
\end{tabular}

Numbers between brackets correspond to the number of municipalities included in each metropolitan area.

Source: INE, Padrón continuo (www.ine.es/inebmenu/mnu_padron.htm).

\section{Economic crisis and urban growth}

Figure 3 shows that, during the economic expansion period lasting from the late 1990s until the third quarter of 2007, Spain's annual employment growth rates averaged 4\% (Figure 3). These new jobs, basically in the construction and service sectors, attracted millions of foreign migrants. Consequently, annual entries of foreign immigrants increased from 300'000 in 2000 to 900'000 in 2007 (Figure 4). Those employed increased from less than 0.5 million in the year 2000 to around 3 million in the first quarter of 2008 (Figure 5). If we took into account foreigners who acquired Spanish citizenship and those who have double nationality, figures would even be larger. 
FigURE 3 Annual employment growth rates (quarterly data compared to one year earlier), Spain 2001-2011

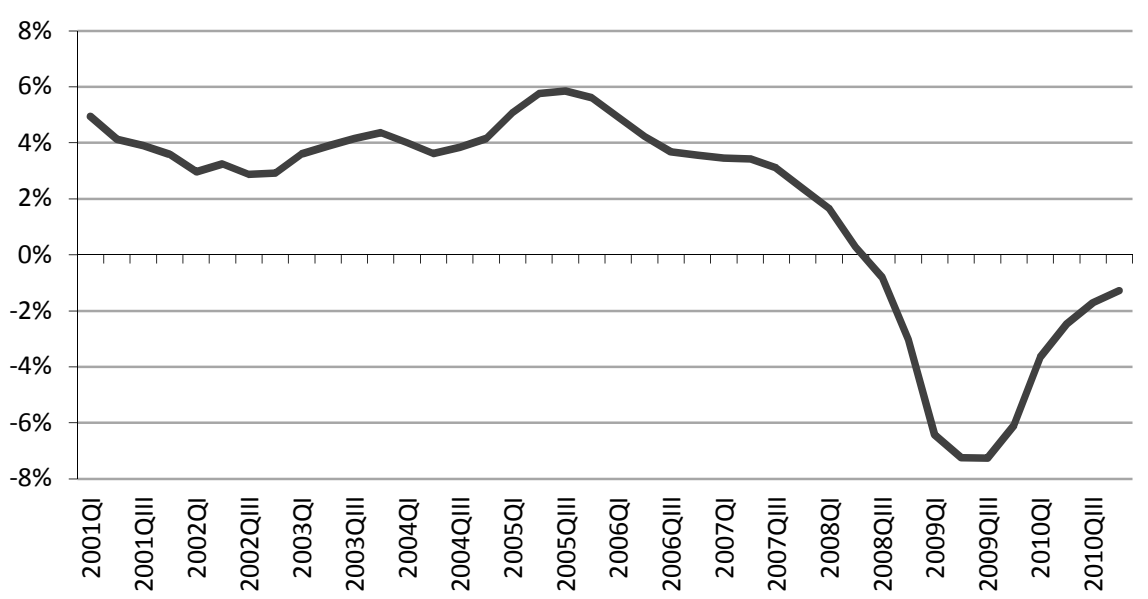

Source: INE, EPA - Spanish Labour Market Survey (www.ine.es/inebmenu/mnu_mercalab.htm).

\section{FIGURE 4 Annual entries of foreign immigrants in Spain, 2000-2010}

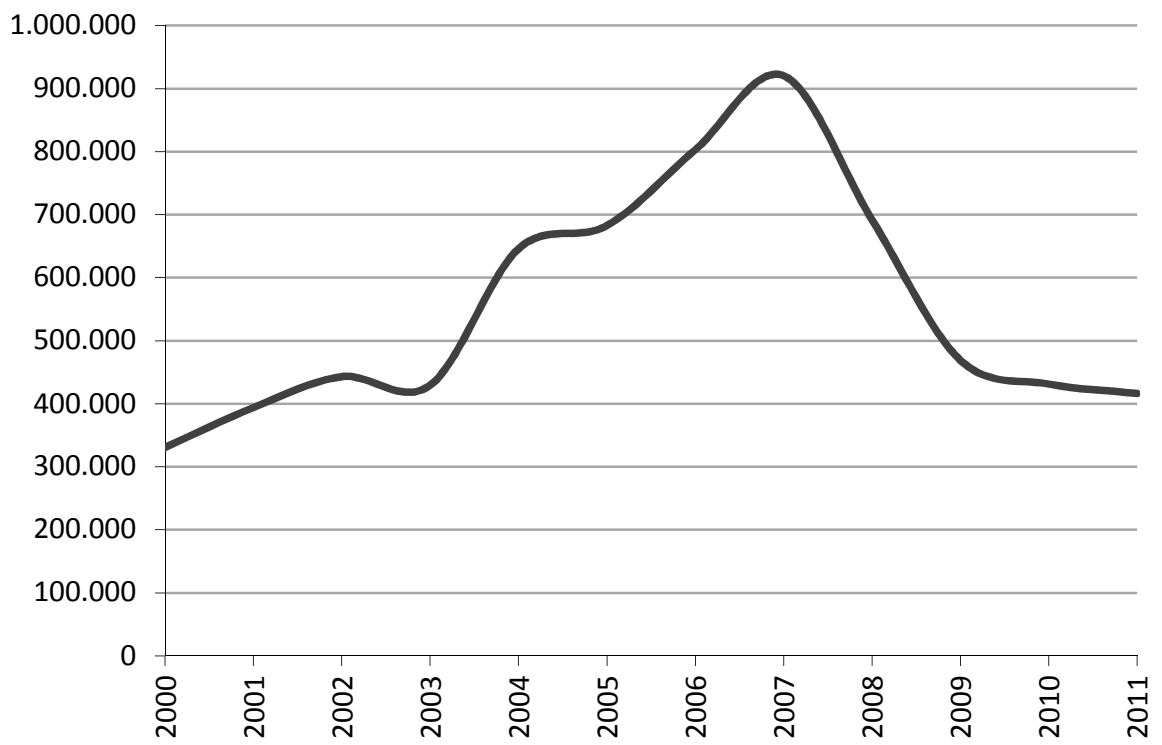

Source: INE, EVR - Residential variation statistics (www.ine.es/inebmenu/mnu_padron.htm). 
Figure 5 Employed foreigners (in thousands), Spain 2000-2010

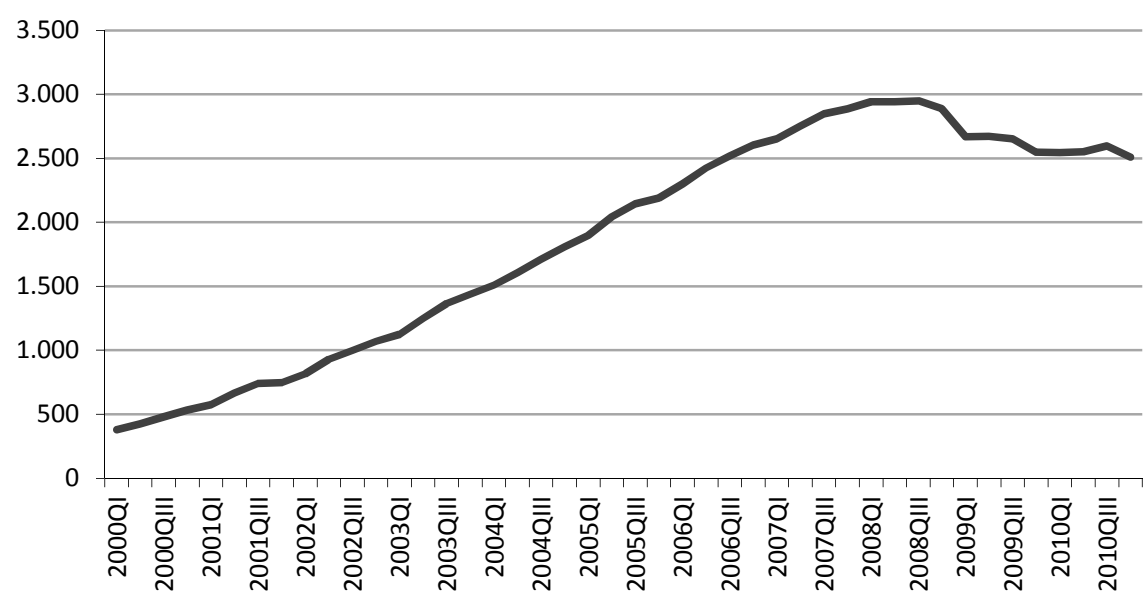

Source: INE, EPS Spanish Labour Market Survey (www.ine.es/inebmenu/mnu_mercalab.htm).

When the current global economic crisis starting in 2007 - which some authors have called The Great Recession - became apparent in Spain in 2008, the property bubble burst and the annual employment growth rate collapsed, rapidly becoming negative (Figure 3 ). In only two years, the number of employed foreigners decreased by half a million (Figure 5). Additionally, the 400 '000 who were unemployed in 2007 rose to 1.2 million at the end of 2010. As employment fell, immigration flows also rapidly did (Figure 5) and the number of foreigners stopped increasing. This trend can also be observed in urban growth data (Table 2).

As expected, results confirm the existence of the two formerly described periods: expansion (2000-2007) and crisis (2008-2010). In the former, demographic growth is higher $(1.73 \%$ annually $)$ than in the latter $(1.06 \%)$. The number of registered foreigners rises more rapidly than that of nationals. Moreover, even during the crisis period this number increased by $4.44 \%$ annually (Table 2 ). However, despite being relatively significant these figures are six times lower than in previous years $(24.76 \%)$. In other words, as observed by their decreasing growth levels, foreigners were heavily impacted. Nevertheless, the growth rates of Spanish people seem to have been less affected by the crisis. In fact they seem to increase more after January 2008 than before that date (rising from an annual $0.39 \%$ to a $0.58 \%$ ). This apparently strange trend could possibly be explained by the number of foreigners who were then acquiring Spanish citizenship. 
TABLE 2 2000-2007 and 2008-2010 population growth by nationality in the main Spanish metropolitan areas

Absolute figures

\begin{tabular}{|l|r|r|r|r|r|r|}
\hline & \multicolumn{3}{|c|}{$2000-2007$} & & $2008-2010$ \\
\hline Alicante-Elche & Spanish & Foreigners & Total & Spanish & Foreigners & \multicolumn{1}{c|}{ Total } \\
\hline Central de Asturias & $41^{\prime} 293$ & $83^{\prime} 391$ & $124^{\prime} 684$ & $6^{\prime} 049$ & $5^{\prime} 236$ & $11^{\prime} 285$ \\
\hline Palma de Mallorca & $-4^{\prime} 916$ & $27^{\prime} 176$ & $22^{\prime} 260$ & $-19^{\prime} 147$ & $27^{\prime} 000$ & $7^{\prime} 853$ \\
\hline Barcelona & $18^{\prime} 362$ & $83^{\prime} 600$ & $101^{\prime} 962$ & $4^{\prime} 738$ & $8^{\prime} 153$ & $12^{\prime} 891$ \\
\hline Bilbao & $23^{\prime} 363$ & $577^{\prime} 042$ & $600^{\prime} 405$ & $29^{\prime} 604$ & $54^{\prime} 505$ & $84^{\prime} 109$ \\
\hline Bahía de Cádiz & $-38^{\prime} 390$ & $38^{\prime} 567$ & 177 & $-4^{\prime} 075$ & $7^{\prime} 761$ & $3^{\prime} 686$ \\
\hline Vigo-Pontevedra & $36^{\prime} 510$ & $11^{\prime} 882$ & $48^{\prime} 392$ & $6^{\prime} 382$ & $1^{\prime} 964$ & $8^{\prime} 346$ \\
\hline Granada & $11^{\prime} 106$ & $19^{\prime} 221$ & $30^{\prime} 327$ & $4^{\prime} 451$ & $1^{\prime} 951$ & $6^{\prime} 402$ \\
\hline Madrid & $40^{\prime} 728$ & $22^{\prime} 009$ & $62^{\prime} 737$ & $15^{\prime} 206$ & $1^{\prime} 810$ & $17^{\prime} 016$ \\
\hline Málaga & $233^{\prime} 122$ & $839^{\prime} 894$ & $1^{\prime} 073^{\prime} 016$ & $112^{\prime} 483$ & $74^{\prime} 563$ & $187^{\prime} 046$ \\
\hline Murcia & $68^{\prime} 755$ & $94^{\prime} 458$ & $163^{\prime} 213$ & $13^{\prime} 678$ & $13^{\prime} 526$ & $27^{\prime} 204$ \\
\hline Palmas Gran Canaria, L. & $41^{\prime} 898$ & $76^{\prime} 787$ & $118^{\prime} 685$ & $11^{\prime} 848$ & $5^{\prime} 976$ & $17^{\prime} 824$ \\
\hline Sevilla & $16^{\prime} 451$ & $21^{\prime} 703$ & $38^{\prime} 154$ & $3^{\prime} 605$ & $1^{\prime} 575$ & $5^{\prime} 180$ \\
\hline Valencia & $57^{\prime} 063$ & $38^{\prime} 512$ & $95^{\prime} 575$ & $17^{\prime} 163$ & $11^{\prime} 227$ & $28^{\prime} 390$ \\
\hline Zaragoza & $22^{\prime} 314$ & $159^{\prime} 435$ & $181^{\prime} 749$ & $9^{\prime} 963$ & $12^{\prime} 916$ & $22^{\prime} 879$ \\
\hline & $6^{\prime} 005$ & $78^{\prime} 401$ & $84^{\prime} 406$ & $5^{\prime} 542$ & $9^{\prime} 697$ & $15^{\prime} 239$ \\
\hline & $573^{\prime} 664$ & $2^{\prime} 172^{\prime} 078$ & $2^{\prime} 745^{\prime} 742$ & $217^{\prime} 490$ & $237^{\prime} 860$ & $455^{\prime} 350$ \\
\hline
\end{tabular}

Annual cumulative growth rates $r(\%)$

\begin{tabular}{|l|c|c|c|c|c|c|}
\hline & \multicolumn{3}{|c|}{$2000-2007$} & \multicolumn{3}{|c|}{$2008-2010$} \\
\hline Alicante-Elche & Spanish & Foreigners & Total & Spanish & Foreigners & Total \\
\hline Central de Asturias & -0.93 & 19.86 & 2.54 & 0.52 & 2.37 & 0.82 \\
\hline Palma de Mallorca & 0.55 & 22.59 & 0.34 & -1.21 & 34.12 & 0.47 \\
\hline Barcelona & 0.07 & 21.36 & 2.69 & 0.55 & 3.77 & 1.20 \\
\hline Bilbao & -0.54 & 25.47 & 0.00 & -0.24 & 8.10 & 0.20 \\
\hline Bahía de Cádiz & 0.77 & 20.24 & 1.00 & 0.52 & 6.18 & 0.66 \\
\hline Vigo-Pontevedra & 0.25 & 20.03 & 0.67 & 0.40 & 3.82 & 0.55 \\
\hline Granada & 1.14 & 25.32 & 1.71 & 1.61 & 3.38 & 1.70 \\
\hline Madrid & 0.57 & 25.30 & 2.37 & 1.06 & 3.64 & 1.48 \\
\hline Málaga & 1.16 & 16.24 & 2.48 & 0.87 & 4.89 & 1.47 \\
\hline Murcia & 1.02 & 36.84 & 2.68 & 1.09 & 3.51 & 1.42 \\
\hline Palmas Gran Canaria, L. & 0.42 & 13.35 & 0.93 & 0.36 & 2.27 & 0.48 \\
\hline Sevilla & 0.60 & 25.26 & 0.99 & 0.71 & 11.51 & 1.12 \\
\hline Valencia & 0.21 & 33.95 & 1.59 & 0.37 & 3.60 & 0.74 \\
\hline Zaragoza & 0.12 & 36.34 & 1.56 & 0.43 & 5.51 & 1.04 \\
\hline & 0.39 & 24.76 & 1.73 & 0.58 & 4.44 & 1.06 \\
\hline Source
\end{tabular}

Source: INE, Padrón continuo (www.ine.es/inebmenu/mnu_padron.htm). 
In comparison to the previous period, most metropolitan areas diminished their growth rates after 2008 even though none of them lost population. Surprisingly enough, there are even three metropolitan areas Bilbao, Asturias and Seville - which gained more inhabitants in this second phase than in the previous one. Despite being stagnant between 2008 and 2010, Bilbao's population slightly increased annually (0.20\%). The Asturias central urban area population continued growing in the second phase and at a faster pace (yearly increasing from $0.34 \%$ to $0.47 \%$ ). Finally, Seville's inhabitants also follow a similar trend (growing yearly from $0.99 \%$ to $1.12 \%$ ). It should additionally be noted that VigoPontevedra and Granada's latter period decrease is rather small. In fact, these five urban areas are precisely those which received less foreign immigration during the expansion period (Table 2). Therefore, it can probably be concluded that they are also those which migration flows have been less affected by the impact of the economic crisis. By contrast, metropolitan areas which received up to 2007 the highest proportions of foreigners have grown considerably less during the crisis period.

\section{Centre periphery differences}

When analysing population dynamics within and between cores and peripheries, geographic differences among the 15 urban areas should first be taken into account. More specifically, two key factors, the core city's area (in $\mathrm{km}^{2}$ ) and the number of municipalities making up each metropolitan region, determine the relative demographic importance of core cities in relation to the rest of their metropolitan area. For instance, the city of Barcelona contains only $32 \%$ of its metropolitan area residents, as it is relatively small $\left(100 \mathrm{~km}^{2}\right)$ and at the centre of a metropolis made of 164 municipalities. At the other end, the city of Zaragoza (974 $\mathrm{km}^{2}$ ) holds $91 \%$ of the inhabitants residing in the 14 municipalities which form its urban area. The same can be asserted about foreigners' core city and periphery spatial distribution (Map 1). 
MAP 1 Centre-periphery distribution of foreigners

in the main Spanish metropolitan areas, 2010

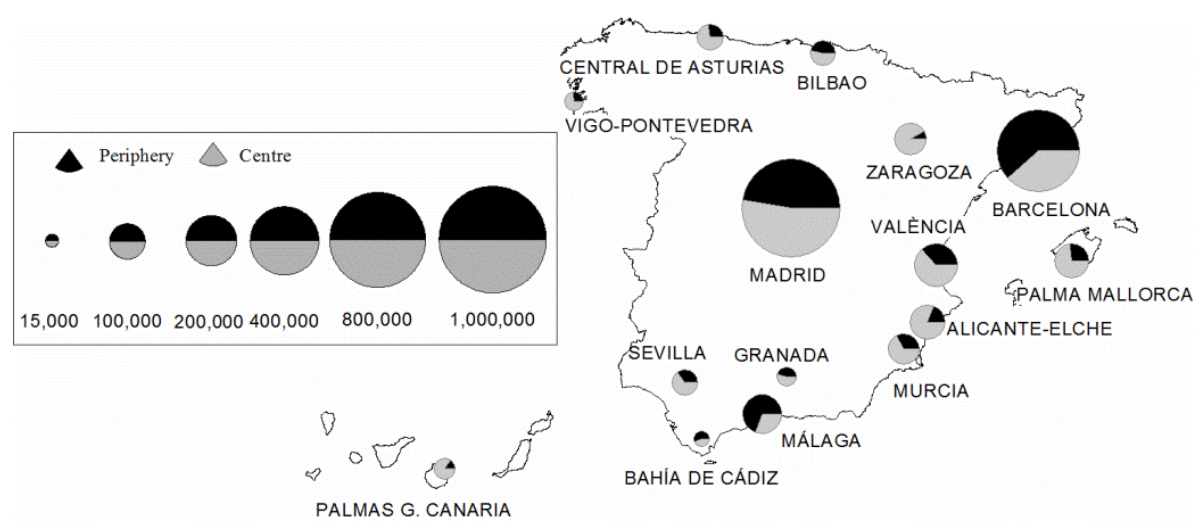

Source: INE, Padrón continuo (www.ine.es/inebmenu/mnu_padron.htm).

During the decade analysed, peripheries generally gained more population than core cities, though the latter also had positive growth. There are only three exceptions to this general pattern, those situated furthest to the right on Figure 6 upper graph. However, they cover slightly different cases. While the central cities of Bilbao and Granada lost population $^{8}$, the two core cities of central Asturias grew whereas the suburb reduced its population. In sum, except for the latter case, which would still be at the initial urbanisation stage (Van den Berg et al., 1982), the rest would be at the de-urbanisation stage. Malaga - where metropolitan population living in the core city fell from $73.8 \%$ in 2000 to $60.3 \%$ in 2010 - and Granada - where it dropped from $56.4 \%$ to $46.7 \%$ - would be the most paradigmatic cases.

8. Between 2000 and 2010, Granada's residents diminished by $0.22 \%$ while its periphery grew $3.81 \%$. Suburbanisation is therefore very significant. The case of Bilbao is slightly different, as its population distribution remained stagnant, its central municipality only increasing by $0.03 \%$ and its periphery by $0.09 \%$. 
FIGURE 6 Centre-periphery Spanish metropolitan area annual cumulative growth rate, $2000-2010$

Total Population

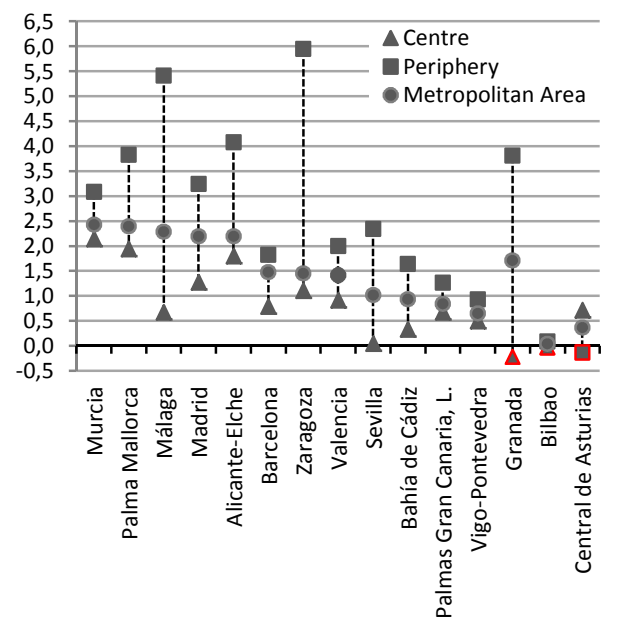

Spaniards

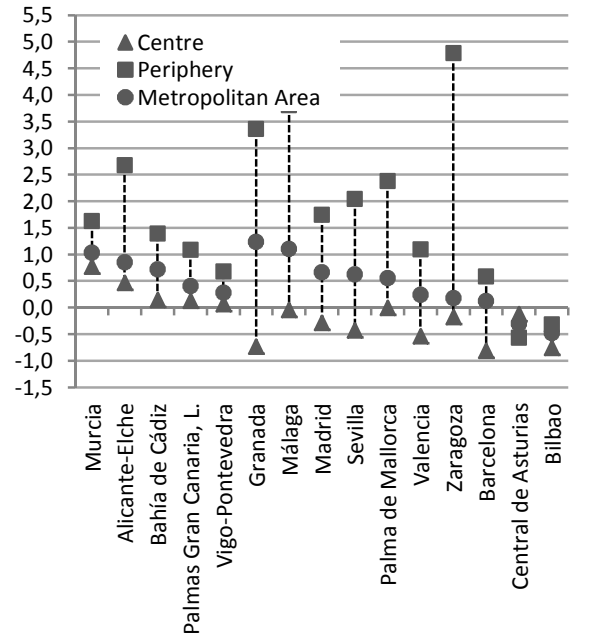

Foreigners

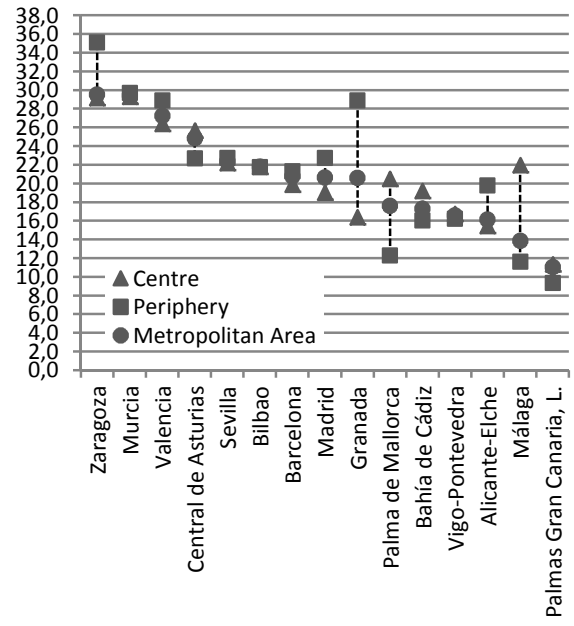

Source: INE, Padrón continuo (www.ine.es/inebmenu/mnu_padron.htm).

From 2000 onwards, demographic growth was basically due to foreign migration (Table 3). Except for Seville and Granada, which lost population due to net emigration, foreigners have strengthened both core city and fringe migratory growth everywhere. 
TABLE $3 \quad 2000-2010$ centre and periphery Spanish metropolitan areas natural and migratory growth

\begin{tabular}{|c|c|c|c|}
\hline & Total growth & Natural change & Net migration \\
\hline Centre & $92^{\prime} 563$ & $19^{\prime} 766$ & $72^{\prime} 797$ \\
\hline Periphery & $43^{\prime} 406$ & $5^{\prime} 726$ & $37^{\prime} 680$ \\
\hline Alicante-Elche & $135^{\prime} 969$ & $25^{\prime} 492$ & $110^{\prime} 477$ \\
\hline Centre & $34^{\prime} 516$ & $-14^{\prime} 158$ & $48^{\prime} 674$ \\
\hline Periphery & $-4^{\prime} 403$ & $-14^{\prime} 160$ & 9'757 \\
\hline Central de Asturias & $30^{\prime} 113$ & $-28^{\prime} 318$ & $58^{\prime} 431$ \\
\hline Centre & $70^{\prime} 756$ & $13^{\prime} 179$ & $57^{\prime} 577$ \\
\hline Periphery & $44^{\prime} 097$ & $6^{\prime} 614$ & $37^{\prime} 483$ \\
\hline Palma de Mallorca & $114^{\prime} 853$ & $19^{\prime} 793$ & $95^{\prime} 060$ \\
\hline Centre & $123^{\prime} 071$ & $-19^{\prime} 106$ & $142^{\prime} 177$ \\
\hline Periphery & $561^{\prime} 443$ & $150^{\prime} 871$ & $410^{\prime} 572$ \\
\hline Barcelona & $684^{\prime} 514$ & $131^{\prime} 765$ & $552^{\prime} 749$ \\
\hline Centre & $-1^{\prime} 084$ & $-6^{\prime} 669$ & $5^{\prime} 585$ \\
\hline Periphery & $4^{\prime} 947$ & 579 & $4^{\prime} 368$ \\
\hline Bilbao & 3'863 & $-6^{\prime} 090$ & 9'953 \\
\hline Centre & $10^{\prime} 984$ & $8^{\prime} 652$ & 2’332 \\
\hline Periphery & $45^{\prime} 754$ & $18^{\prime} 933$ & $26^{\prime} 821$ \\
\hline Bahía Cádiz & $56^{\prime} 738$ & $27^{\prime} 585$ & $29^{\prime} 153$ \\
\hline Centre & $18^{\prime} 367$ & 3'569 & $14^{\prime} 798$ \\
\hline Periphery & $18^{\prime} 362$ & $3^{\prime} 363$ & $14^{\prime} 999$ \\
\hline Vigo-Pontevedra & $36^{\prime} 729$ & 6'932 & $29^{\prime} 797$ \\
\hline Centre & $-5^{\prime} 332$ & $2 ' 726$ & $-8^{\prime} 058$ \\
\hline Periphery & $85^{\prime} 085$ & $17 ’ 289$ & $67^{\prime} 796$ \\
\hline Granada & $79^{\prime} 753$ & $20^{\prime} 015$ & $59^{\prime} 738$ \\
\hline Centre & $390 \prime 189$ & $59 \prime 275$ & $330^{\prime} 914$ \\
\hline Periphery & $869^{\prime} 873$ & $225^{\prime} 112$ & $644^{\prime} 761$ \\
\hline Madrid & $1^{\prime} 260^{\prime} 062$ & $284^{\prime} 387$ & $975^{\prime} 675$ \\
\hline Centre & $36^{\prime} 942$ & $17^{\prime} 312$ & $19^{\prime} 630$ \\
\hline Periphery & $153^{\prime} 475$ & $18^{\prime} 155$ & $135^{\prime} 320$ \\
\hline Málaga & $190^{\prime} 417$ & $35^{\prime} 467$ & $154^{\prime} 950$ \\
\hline Centre & $84^{\prime} 179$ & $23^{\prime} 198$ & $60 ’ 981$ \\
\hline Periphery & $52 \prime 330$ & $13^{\prime} 103$ & $39^{\prime} 227$ \\
\hline Murcia & $136^{\prime} 509$ & $36 ’ 301$ & $100 \prime 208$ \\
\hline Centre & $24^{\prime} 790$ & $8^{\prime} 428$ & $16^{\prime} 362$ \\
\hline Periphery & $18^{\prime} 544$ & $6^{\prime} 584$ & $11^{\prime} 960$ \\
\hline Palmas G. Canaria, L. & $43^{\prime} 334$ & $15^{\prime} 012$ & $28^{\prime} 322$ \\
\hline Centre & $3^{\prime} 482$ & $18^{\prime} 382$ & $-14^{\prime} 900$ \\
\hline Periphery & $120^{\prime} 483$ & 37799 & $82^{\prime} 684$ \\
\hline Sevilla & $123^{\prime} 965$ & $56^{\prime} 181$ & $67^{\prime} 784$ \\
\hline Centre & $70^{\prime} 253$ & $8^{\prime} 508$ & $61^{\prime} 745$ \\
\hline Periphery & $134^{\prime} 375$ & $28^{\prime} 027$ & $106^{\prime} 348$ \\
\hline Valencia & $204^{\prime} 628$ & $36 \prime 535$ & $168^{\prime} 093$ \\
\hline Centre & $70^{\prime} 490$ & $5 \prime 112$ & $65^{\prime} 378$ \\
\hline Periphery & $29^{\prime} 155$ & $3 ' 180$ & $25^{\prime} 975$ \\
\hline Zaragoza & $99^{\prime} 645$ & $8^{\prime} 292$ & $91^{\prime} 353$ \\
\hline
\end{tabular}

Source: INE, Padrón continuo (www.ine.es/inebmenu/mnu padron.htm) and MNP (www.ine.es/inebmenu/mnu_dinamicapob.htm). 
TABLE $4 \quad 2000,2008$ and 2010 Centre and periphery metropolitan area foreigner percentages

\begin{tabular}{|c|c|c|c|}
\hline & 2000 & 2008 & 2010 \\
\hline Centre & 4,7 & 16,0 & 16,5 \\
\hline Periphery & 3,9 & 15,6 & 16,1 \\
\hline Alicante-Elche & 4,6 & 15,9 & 16,4 \\
\hline Centre & 1,0 & 5,1 & 8,9 \\
\hline Periphery & 0,6 & 2,5 & 4,8 \\
\hline Central de Asturias & 0,8 & 4,1 & 7,3 \\
\hline Centre & 3,9 & 19,5 & 20,7 \\
\hline Periphery & 9,9 & 21,2 & 21,7 \\
\hline Palma de Mallorca & 5,2 & 19,9 & 21,0 \\
\hline Centre & 3,1 & 16,9 & 17,5 \\
\hline Periphery & 2,4 & 12,6 & 13,6 \\
\hline Barcelona & 2,6 & 14,0 & 14,9 \\
\hline Centre & 1,1 & 7,1 & 8,0 \\
\hline Periphery & 0,6 & 3,8 & 4,6 \\
\hline Bilbao & 0,8 & 5,1 & 5,9 \\
\hline Centre & 0,4 & 1,9 & 2,2 \\
\hline Periphery & 0,9 & 3,0 & 3,3 \\
\hline Bahía Cádiz & 0,6 & 2,4 & 2,7 \\
\hline Centre & 1,2 & 5,1 & 5,3 \\
\hline Periphery & 0,8 & 2,9 & 3,3 \\
\hline Vigo-Pontevedra & 1,1 & 4,3 & 4,6 \\
\hline Centre & 1,3 & 6,4 & 6,3 \\
\hline Periphery & 0,6 & 4,3 & 4,8 \\
\hline Granada & 1,0 & 5,3 & 5,5 \\
\hline Centre & 3,4 & 16,8 & 17,4 \\
\hline Periphery & 2,9 & 15,2 & 16,1 \\
\hline Madrid & 3,2 & 16,0 & 16,7 \\
\hline Centre & 1,2 & 7,1 & 8,0 \\
\hline Periphery & 15,5 & 27,0 & 27,5 \\
\hline Málaga & 5,4 & 14,7 & 15,7 \\
\hline Centre & 1,3 & 13,0 & 13,7 \\
\hline Periphery & 1,5 & 14,2 & 14,5 \\
\hline Murcia & 1,3 & 13,4 & 14,0 \\
\hline Centre & 2,9 & 7,8 & 8,0 \\
\hline Periphery & 1,5 & 3,0 & 3,2 \\
\hline Palmas G. Canaria, L. & 2,5 & 6,4 & 6,6 \\
\hline Centre & 0,7 & 4,3 & 5,3 \\
\hline Periphery & 0,6 & 2,9 & 3,4 \\
\hline Sevilla & 0,7 & 3,7 & 4,5 \\
\hline Centre & 1,6 & 14,2 & 14,8 \\
\hline Periphery & 0,9 & 8,5 & 9,3 \\
\hline Valencia & 1,3 & 11,5 & 12,2 \\
\hline Centre & 1,1 & 11,9 & 13,0 \\
\hline Periphery & 1,0 & 10,4 & 11,3 \\
\hline Zaragoza & 1,1 & 11,8 & 12,8 \\
\hline
\end{tabular}

Source: INE, Padrón continuo (www.ine.es/inebmenu/mnu_padron.htm). 
At the same time, these large numbers of immigrants have led to a birth rise allowing natural growth to resume. Therefore, natural growth has become positive almost everywhere. Barcelona and Bilbao cores, and the whole of Asturias urban area, would be the only three exceptions (Table 3).

Considering Spanish nationals (Figure 6, left) trends turn out to be quite different. In eight cases, including Barcelona and Madrid and the other main metropolitan areas, the Spanish population increased in suburbs while decreasing in core cities. Only five cores (Murcia, Alicante-Elche, Jerez-Cadiz, Las Palmas and Vigo-Pontevedra) gained Spaniards - even though not as much as their peripheries. Finally, both the centres and the peripheries of Asturias and Bilbao lost nationals.

On the opposite side - and as Figure 3 (right) shows - foreigner figures have highly and widely grown throughout all metropolitan areas ${ }^{9}$. As a consequence both centre and periphery foreigner shares have increased continually since 2000 (Table 4). It should also be noted, that they now no longer grow at the same pace.

In 2010, Malaga's periphery (27.5\%) has the highest proportion of foreigners while Las Palmas de Gran Canarias' suburb has the lowest one (3.2\%). On the other hand, the cities of Palma de Mallorca (20.7\%), Barcelona (17.5\%) and Madrid (17.4\%) have the highest core city foreigner shares and the two Bahía de Cadiz centres have the lowest ones $(2.2 \%)$.

Figure 7 differentiates core city and fringe population increase during economic growth and crisis periods. Except for Granada, Bilbao and Seville, all other core cities grew between 2000 and 2007 though peripheries increased even more. Zaragoza and Malaga are particularly significant cases. Asturias, where periphery population diminished, would be the only exception (Figure 7, upper left). This generalised urban centre expansion cannot be understood without the enormous foreign inflows they received (Figure 7, lower left), which, in eight of the cores, even compensated the diminishing Spanish populations. The cases of Granada (where Spaniards decreased by $-1.04 \%$ annually) and Barcelona $(-0.96 \%$ annually) would stand out. In the other seven cores, Spanish residents remained stable or slightly increased (Figure 7, centre left). On the other hand, except for the central Asturias (-0.47\%) and Bilbao

9. Nevertheless, their settlement patterns seem somewhat obscure, as Granada, Zaragoza, Alicante-Elche, Madrid, Valencia or Barcelona would indicate that foreigners prefer living in the periphery while Malaga, Palma de Mallorca o Bahía de Cadiz would seem to point in the opposite direction. 
$(-0.38 \%)$, all the other peripheries gained Spanish residents between 2000 and 2007.

The 2008-2010 economic crisis seems to have particularly affected peripheries and those centres which grew more during the previous period. By contrast, core cities receiving fewer immigrants during economic expansion years are also those less impacted by the crisis. Cities like Seville and Granada, which lost population before 2008, even experience a small positive growth during the last three years of the decade (Figure 7, upper right).

Differences in foreigner figures between the two periods are particularly striking as in the latter part of the decade their numbers significantly reduced both in core cities and peripheries (Figure 7 , lower right). The city of Granada is a particularly notable case as its foreigner growth rates even became negative. Decreasing immigration flows due to the economic crisis would explain this trend.

As for Spanish population, their growth rates seem to be less affected by the crisis than those of foreigners. However, their suburbanisation flows do tend to slow down due to the effect of economic crisis on the construction and housing markets. Subsequently, peripheries gain less Spaniards as they are leaving less from core cities. In fact, the number of cores losing Spanish residents reduces from 8 to 6. Four cities (including Madrid) that lost Spaniards before 2008 start gaining them once again. Nevertheless Barcelona, Valencia, Seville and Bilbao, lost Spanish residents in both periods, though less during the second one. Other cities gained nationals throughout the whole decade, particularly at the end of it. 
Figure 7 Centre and periphery Spanish metropolitan area annual cumulative growth rate, 2000-2007 and 2008-2010

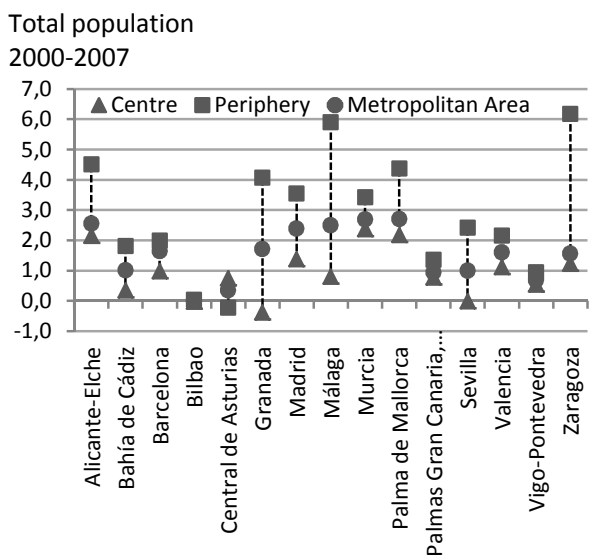
$2008-2010$

Spaniards 2000-2007
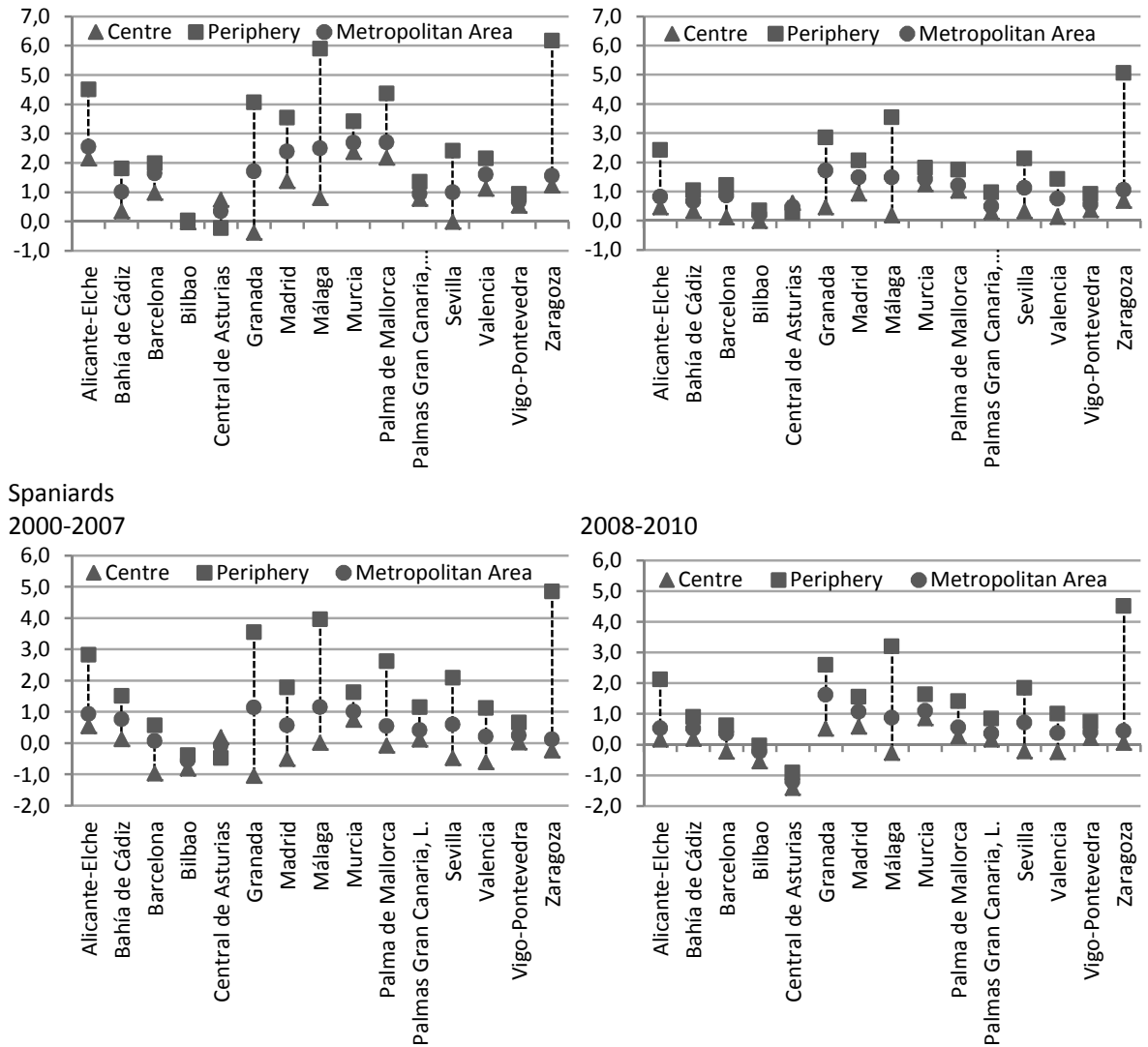

2008-2010

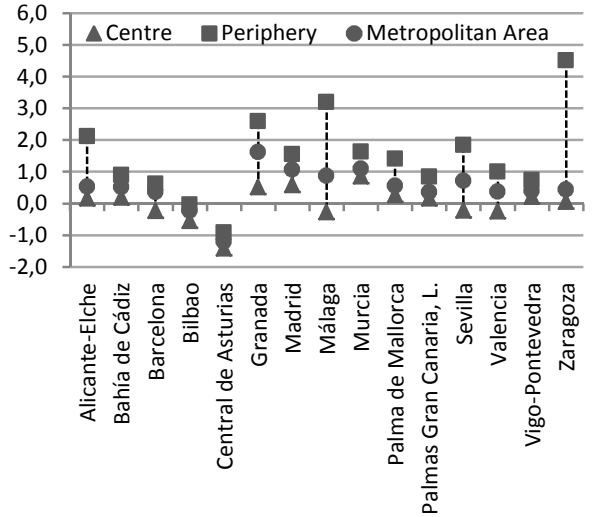

Foreigners

2000-2007

2008-2010
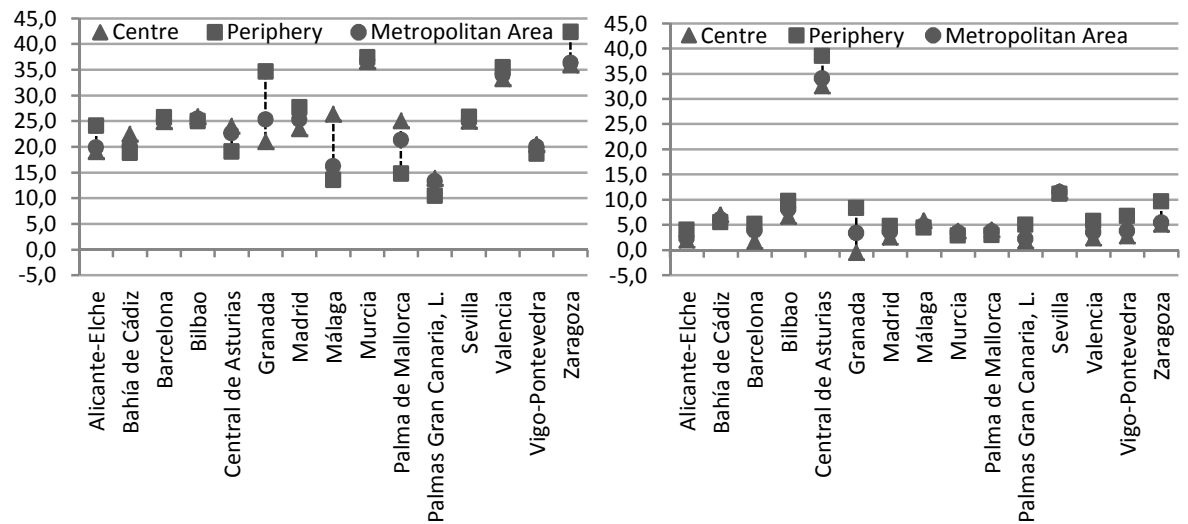

Source: INE, Padrón continuo (www.ine.es/inebmenu/mnu_padron.htm). 


\section{Conclusions and discussion}

As a result of an increase in foreign immigration, all the largest Spanish metropolitan areas have experienced an increase of population. However, growth rates have been extremely different. While the metropolis of Bilbao has remained relatively stable, Madrid has increased by about 1'250'000 inhabitants.

Despite this diversity, a general trend is observed: the more foreigners an urban area has received, the more it has grown. The most significant growths have taken place not only in Madrid, but also in Mediterranean coastal urban areas such as Palma de Mallorca, Alicante, Murcia or Malaga, i. e. the ones which in relative terms have received more immigrants.

Population trends indicate that without immigrants Spain's urban growth would have still been positive but much lower. In the cases of Asturias and Bilbao urban areas, it would have even been negative.

Population growth has been more significant in suburban municipalities than in urban cores. Still, most of these central cities have gained population through international immigration as, at least initially, foreign migrants tend to concentrate in urban centres. Starting from these, they have progressively contributed to the suburbanisation process.

Since 2008 the economic and real estate crisis seem to have restrained urban area population growth and suburbanization dynamics. On the one hand, fewer foreigners immigrated so metropolitan population has slowed down its growth. On the other hand, getting access to new dwellings has become more difficult. The economic, financial and particularly the housing market crises have led the construction sector to collapse, while access to mortgage loans has been heavily restricted. Spanish population is subsequently moving less and suburbanisation flows from core cities to peripheries have diminished. Urban centres are even gaining Spanish nationals, or losing less of them in comparison to before the recession.

Finally, empirical results confirm that the theoretical Van den Berg et al. (1982) model is not fully adequate to explain recent changes in Spain. The four-stage model of urban development needs to be adapted. The first urbanisation stage would have been followed by the suburbanisation one, then by a third phase in which foreign inflows simultaneously produce core growth and suburbanisation, and finally, by a fourth stage characterised, under the influx of the current crisis, by low urban growth and relative recentralisation. Future research will tell whether 
both international immigration and recession - which are factors not considered in Van den Berg et al. model - have been acting in the Spanish case as circumstantial or structural factors, and whether they can determine future urban development in the same way they did this last decade.

\section{References}

ANDERSEN H. S. (2003), Urban Sores: On the Interaction between Segregation, Urban Decay, and Deprived Neighbourhoods, Ashgate, Farnham (UK).

BAYONA J., GIL-ALonso F. (2008), «El papel de la inmigración extranjera en la expansión de las áreas urbanas. El caso de Barcelona (1998-2007)», Scripta Nova, 270 (132).

BAYONA J. (2007), "La segregación residencial de la población extranjera en Barcelona: ¿una segregación fragmentada?», Scripta Nova, 11 (235).

Buzar S., Ogden P. E., Hall R. (2005), «Households Matter: The Quiet Demography of Urban Transformation", Progress in Human Geography, 29, pp. 413-436, http:// dx.doi.org/10.1191/0309132505ph5580a.

CHAMPION T. (2001a), «Urbanization, Suburbanization, Counterurbanization and Reurbanization", Handbook of Urban Studies, R. PADDISON (ed), SAGE, London, pp. 143-161, http://dx.doi.org/10.4135/9781848608375.n9.

CHAMPION T. (2001b), «A Changing Demographic Regime and Evolving Polycentric Urban Regions: Consequences for the Size, Composition and Distribution of City Populations», Urban Studies, 38, pp.657-677, http://dx.doi.org/10.1080/ 00420980120035277.

CHESHIRE P. (1995), «A New Phase of Urban Development in Western Europe? The Evidence for the 1980s», Urban Studies, 32 (7), pp. 1'045-1'063.

Domingo A., GIL-Alonso F. (2007), «Immigration and Changing Labour Force Structure in the Southern European Union» Population (English edition), 62 (4), pp. 709727, http://dx.doi.org/10.3917/pope.704.0709.

Domingo A., Recaño J. (2010), "La inflexión del ciclo migratorio internacional en España: impacto y consecuencias demográficas», La inmigración en tiempos de crisis, E. AJA, J. ARANGo, J. Oliver (eds), Anuario de la Inmigración en España. Barcelona, Fundació CIDOB.

Ebers M. (2007), Shrinking Cities, the Hidden Challenge, Grin Verlag, Norderstedt.

FerIA J. M. (2011), "Ciudad y Territorio. Nuevas dinámicas espaciales», Población y Espacios Urbanos, I. PUJADAs et al. (eds), Human Geography Department (UB) and AGE Population Group, Barcelona, pp. 13-52. 
GiL-Alonso F., Domingo A. (2008), «Latinoamericanos en el mercado de trabajo español, 2000-05», Papeles de Población, 55, pp. 145-172.

HAASe A., KABISCH S., SteinfüHrer A. (2005), «Reurbanisation of Inner-City Areas in European Cities: Scrutinizing a Concept of Urban Development with Reference to Demographic and Household Change», Society, Economy, Environment - Towards the Sustainable City, I. SAGAN, D. M. SMITH (eds), Bogucki Wydawnictwo Naukowe, Gdansk and Poznan, pp. 75-91.

Hall P. (2006), "Aged Industrial Countries», Atlas of Shrinking Cities, P. Oswalt, T. RIENIETS (eds), Ostfildern, pp. 144-145.

InStituto De Demografía (1994), Proyección de la población española, Instituto de Demografía/C. S. I. C., Madrid.

KABISCH N., HAASE D. (2011), «Diversifying European Agglomerations: Evidence of Urban Population Trends for the 21st Century", Population, Space and Place, 17, pp. 236-253, http://dx.doi.org/10.1002/psp.600.

Lesthaeghe R. (1995), "The Second Demographic Transition in Western Countries: An Interpretation", Gender and Family Change in Industrialized Countries, in K. MASON, A.-M. JENSEN (eds), Oxford, Clarendon Press, pp. 17-62.

LEVER W. F. (1993), «Reurbanisation: The policy implications», Urban Studies, 30, pp. 267-284, http://dx.doi.org/10.1080/00420989320080281.

LóPEZ-GAY A. (2011), «¿Vuelve el centro? Caracterización demográfica de los procesos de reurbanización en las metrópolis españolas», Población y Espacios urbanos, I. PUJADAS et al. (eds), Human Geography Department (UB) and AGE Population Group, Barcelona, pp. 163-180.

Medhurst F., LeWIS J. P. (1969), Urban Decay: An Analysis and a Policy, Macmillan.

Ministro de La Vivienda (2006), Atlas Estadístico de las Áreas urbanas en España, I. S. B. N. 978-84-96387-33-1.

NeL-Lo O. (2004), «¿Cambio de siglo, cambio de ciclo? Las grandes ciudades españolas en el umbral del siglo XX|», Ciudad y territorio. Estudios Territoriales, 36 (141142), pp. 523-542.

NeL-Lo O. (2007), "La tercera fase del proceso de metropolitanización en España», Los procesos urbanos postfordistas, O. RULLAN et al. (Ed.), AGE and Universitat de les Illes Balears, Palma de Mallorca.

Ogden P. E., Hall R. (2000), «Households, Reurbanisation and the Rise of Living Alone in the Principal French Cities 1975-1990», Urban Studies, 37, pp. 367-390, http://dx.doi.org/10.1080/0042098002230.

Oswalt P. (2003), Shrinking Cities: International research, Hatje Cantz, Ostfildern.

Pozo E., García-Palomares J. C. (2011), «Evolución reciente y pautas de distribución espacial de las migraciones internas de extranjeros: el caso de la Comunidad de Madrid (1997-2008)», Scripta Nova, 15 (384). 
PujAdAs I., BAyona J., GiL-Alonso F. (2012), «Las grandes metrópolis españolas en la encrucijada. Crecimiento, migración y suburbanización en la última década», Contexto, Revista de la Facultad de Arquitectura Universidad Autónoma de Nuevo León, 6, pp. 11-32.

SERRANo J. M. (2007), «Progresiva polarización demográfica de las aglomeraciones urbanas en España dentro de sus ámbitos provinciales», Geographicalia, 51, pp. 2957.

Turok I., Myknnenko V. (2007), "The Trajectories of European Cities, 1960-2005», Cities, 24, pp. 165-182.

VAN DE KAA D. J. (1987), "Europe's Second Demographic Transition», Population Bulletin, 42 (1), pp. 1-59.

Van den Berg L., Drewett R., KlaAsen L. H., Rossi A., Vijverberg C. H. T. (1982), Urban Europe: A Study of Growth and Decline, Pergamon, Oxford.

Vono D. (2010), ¿Preferidos y favorecidos? El proceso de asentamiento de la población latinoamericana en España, PhD, www.tdx.cat/handle/10803/32142. 